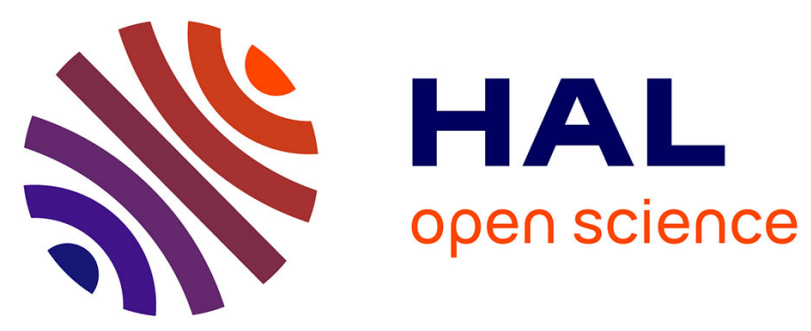

\title{
Segmentation of the Nazca and South American plates along the Ecuador subduction zone from wide angle seismic profiles
}

\author{
A. Gailler, Philippe Charvis, E. R. Flueh
}

\section{- To cite this version:}

A. Gailler, Philippe Charvis, E. R. Flueh. Segmentation of the Nazca and South American plates along the Ecuador subduction zone from wide angle seismic profiles. Earth and Planetary Science Letters, 2007, 260 (3-4), pp.444-464. 10.1016/j.epsl.2007.05.045 . ird-00194762

\section{HAL Id: ird-00194762 \\ https://hal.ird.fr/ird-00194762}

Submitted on 7 Dec 2007

HAL is a multi-disciplinary open access archive for the deposit and dissemination of scientific research documents, whether they are published or not. The documents may come from teaching and research institutions in France or abroad, or from public or private research centers.
L'archive ouverte pluridisciplinaire HAL, est destinée au dépôt et à la diffusion de documents scientifiques de niveau recherche, publiés ou non, émanant des établissements d'enseignement et de recherche français ou étrangers, des laboratoires publics ou privés. 


\title{
Segmentation of the Nazca and South American plates along the Ecuador subduction zone from wide angle seismic profiles
}

\author{
Audrey Gailler, Philippe Charvis \\ Géosciences Azur, Unité mixte de recherche Université de Nice Sophia Antipolis - Institut de Recherche pour le \\ Développement (IRD) - Centre National de la Recherche Scientifique (CNRS) - Université Pierre et Marie Curie \\ - F-06235, BP 48 Villefranche-sur-mer, France.
}

Ernst R. Flueh

IFM-GEOMAR, Research Center for Marine Sciences, 24148, Kiel, Germany.

\begin{abstract}
We describe the deep structure of the south Colombian - northern Ecuador convergent margin using travel time inversion of wide-angle seismic data recently collected offshore. The margin appears segmented into three contrasting zones. In the North Zone, affected by four great subduction earthquakes during the $20^{\text {th }}$ century, normal oceanic crust subducts beneath the oceanic Cretaceous substratum of the margin underlined by seismic velocities as high as $6.0-6.5-\mathrm{km} / \mathrm{s}$. In the Central Zone the subducting oceanic crust is over-thickened beneath the Carnegie Ridge. A steeper slope and a welldeveloped, high velocity, Cretaceous oceanic basement characterizes the margin wedge. This area coincides with a gap in significant subduction earthquake activity. In the South Zone, the subducting oceanic crust is normal. The fore-arc is characterized by large sedimentary basins suggesting significant subsidence. Velocities in the margin wedge are significantly lower and denote a different nature or a higher degree of fracturing.

Even if the distance between the three profiles exceeds $150 \mathrm{~km}$, the structural segmentation obtained along the Ecuadorian margin correlates well with the distribution of seismic activity and the neotectonic zonation.
\end{abstract}

\section{Introduction and tectonic setting}

The Ecuador margin $\left(3.0^{\circ} \mathrm{N}-3.5^{\circ} \mathrm{S}\right)$ represents a region of intense crustal deformation, related to the subduction of the oceanic Nazca plate beneath the South-American continental plate, along a $\mathrm{N} 90^{\circ} \mathrm{E}$ direction and at a rate of $\sim 58-\mathrm{mm} / \mathrm{yr}$ [1]. The margin undergoes shortening perpendicular to the trench axis, involving the north Andean block expulsion at $\sim 6 \mathrm{~mm} / \mathrm{y}$ [1] to the Northeast, parallel to the margin (Fig. 1).

The oceanic Nazca plate in this area has an age to less than 26 My [2], and carries the Carnegie Ridge (CR), which testifies to the interaction between the Galapagos hotspot (GHS) and the Cocos-Nazca spreading centre since $\sim 20$ My (e.g., [3]). Its subduction beneath the Ecuadorian coast induces lateral variations of seismicity, arc magmatism, deformations, vertical motion and sediment distribution along the margin $[4,5]$. The Nazca plate is also marked by huge scarps such as the Yaquina Graben, interpreted as a transform fault associated with the remnant East Malpelo spreading axis $[2,6,7]$ (Fig. 1).

The Ecuador margin consists of the oceanic North-Andean block which was accreted to the Brazilian continental craton during the Cretaceous [8]. These oceanic terranes forming the Ecuadorian margin substratum seem to extend southward into northern Peru (i.e., Banco Peru; Fig. 1) [9]. They consist of tholeitic/andesitic basalts and pillow lavas associated with siliceous sediments, defined as the Piñon Formation. In Ecuador, the Piñon Formation is overlain by an intra-oceanic volcanic arcs series, such as the Cayo formation (e.g., $[10,11])$. To the north (south Colombia, Gorgona Island), outcrops of Cretaceous oceanic terranes (mafic to ultramafic rocks) are associated with the Diabasico Formation [12-14]. 
Several studies on deformation of Andean coastal basins (e.g. [15]) have shown that the margin has undergone a generally compressive regime since accretion of the oceanic terranes to the Ecuadorian paleo-margin ( $\sim 90 \mathrm{My}$ ago). This compressive regime appears largely disturbed in the Gulf of Guayaquil (GG) area, where the tectonic structures testify to a N-S trending opening of the GG basin. The development of this deepest sedimentary basin of the Ecuadorian fore-arc during the last $5 \mathrm{Ma}$ is believed to have resulted from the escape of the north Andean block to the N-E (Fig. 1) [16].

Recent coastal uplift facing CR is indicated by Pliocene marine terraces (Tablazos) exposed at 200$300-\mathrm{m}$ elevations $[17,18]$. To the north, the morphology of the margin, the diversion of drainage networks and increases in coastal accretion support an active subsidence in relation to the seismic activity of the margin [19]. To the south, the GG area appears also as a globally subsiding zone (e.g. [16]).

Our group conducted two major marine seismic experiments along the south Colombia-Ecuador convergent margin: the SISTEUR cruise in 2000 [4], and the SALIERI cruise in 2001 [20]. These surveys provided a unique set of high-quality wide-angle reflection/refraction and multichannel seismic data (MCS) that enabled us to image the structure of both plates as well as the geometry and properties of the inter-plate zone.

This paper, based on the tomographic inversion of 3 wide-angle seismic profiles shot across the margin (Fig. 1), provides the first overview of the structure of the crust and upper mantle of the Nazca and South American plates at the South Colombia - Ecuador subduction zone. We will then tentatively correlate long wavelength structural variations observed along the margin with subduction processes and large subduction earthquakes.

\section{Data acquisition}

During the SISTEUR cruise, wide-angle seismic data were acquired using a seismic source composed of an array of eight 16-1 airguns, shot at $125 \mathrm{~m}$ intervals. During the SALIERI cruise, the seismic source was composed of up to three 32-1 airguns; in this case, the shot interval was set at a time of $60 \mathrm{~s}$ leading to a $\sim 140 \mathrm{~m}$ shot spacing. 24 UTIG-IRD OBS [21] and up to 10 land-seismometers were used during the SISTEUR cruise, whereas 26 UTIG-IRD OBS and 24 GEOMAR OBH and OBS [20] were used during the SALIERI cruise.

Most of the wide-angle data were of good quality, showing clear intracrustal refracted phases ( $\mathrm{Pg})$, deeper arrivals refracted in the upper mantle $(\mathrm{Pn})$, and reflections at the boundary between the subducting oceanic crust and the mantle (PmP) (Fig. 2-4, table 1-3). Pg is here used as a generic term to indicate all the first arrivals that are not refracted in the mantle (sediments and basement).

Significant variations were observed between record sections for instruments located in deep water, shallow-water and on-land instruments. This is probably related to the strong change in the bathymetry (more than $3000 \mathrm{~m}$ ) across the margin but also to the strong lateral variation in the crustal structure along each profile.

\subsection{Record sections for OBS located seaward from the trench}

OBS located on top of the Nazca plate, seaward from the trench, show Pg phases with apparent velocities ranging from 2.5 to $\sim 6.0 \mathrm{~km} / \mathrm{s}$. South of the CR, Pg phases rapidly reach apparent velocities higher than $5 \mathrm{~km} / \mathrm{s}$ at near offset (Fig. 4, OBH 45 and Fig. 3, OBS 04). In contrast, the apparent velocity of Pg phases is less than $4 \mathrm{~km} / \mathrm{s}$ north of the CR (OBH 116, Fig. 2).

At larger offsets, apparent velocities of first arrivals generally exceed $7.0-7.5 \mathrm{~km} / \mathrm{s}$ on most record sections. This has been interpreted to correspond to refraction in the upper mantle (Pn), except westward of OBS 04 (Fig. 3) located on top of the CR along profile SIS-4 where the Pn phase is lacking. In this section (Fig. 3) the apparent velocity, up to $40 \mathrm{~km}$ offset, is $7 \mathrm{~km} / \mathrm{s}$ and probably corresponds to refraction within the subducting oceanic crust. Good quality PmP arrivals are also observed. 


\subsection{Record sections for OBS located landward from the trench}

For OBS located on the continental slope and shelf Pg arrivals are characterized by low apparent velocities (from 2 to $4 \mathrm{~km} / \mathrm{s}$ ) up to $50 \mathrm{~km}$ along profile SAL-2 (OBS 57, Fig. 4). A shadow zone is observable on many instruments located along profiles SAL-6 and SIS-4 (Fig. 2 and 3; OBS 121 and 10 respectively). In both cases, this shadow zone occurs between Pg phases with apparent velocities of $\sim 4 \mathrm{~km} / \mathrm{s}$ and $\sim 6 \mathrm{~km} / \mathrm{s}$. Along profile SAL- 6 , the shadow zone is $\sim 0.5 \mathrm{~s}$ thick.

At larger offsets $(>50-60 \mathrm{~km})$, Pn arrivals are identified as first arrivals on most record sections along the three profiles. PmP arrivals are observed to be variable in quality (e.g., SAL-6; Fig. 2, OBS 121).

\subsection{Travel time picking}

Travel times of refracted $(\mathrm{Pg}, \mathrm{Pn})$ and reflected $(\mathrm{PmP})$ phases identified in the record sections were picked manually (table 1-3). Most of the time, the PmP cannot be identified on the shallow-water instruments. The estimated picking error takes into account the quality of the phase and a possible systematic shift in the arrival identification in order to weight the different picks during the inversion. A 40-50 ms and 60-70 ms picking error was assigned respectively to near offsets and far offset $\mathrm{Pg}$ arrivals. A 80-90 ms error was assumed for Pn phases, and $100 \mathrm{~ms}$ for PmP phases.

\section{Travel Time Tomography}

\subsection{Method}

A joint refraction and reflection travel time tomography method was used to build a two-dimensional velocity model along the three seismic lines [22]. The method allows the simultaneous inversion of first arrival travel times (refracted phases) and a reflection phase, in order to simultaneously determine a 2-D velocity field and the geometry of a floating reflector (not associated with a change in velocity in the model). In this study, we choose to invert the reflector corresponding to the crust-mantle boundary (PmP phase). Detailed descriptions of this method as well as parameters used for the regularization of the inversion can be found in [22].

Using this inversion procedure means that we have to take into account three major issues:

The first issue is due to the inherent non-uniqueness of the inversion solution. The final tomographic model depends on the starting velocity model chosen for the inversion, on the method of linearization and on the geometry of the experiment. The second issue concerns the estimate of uncertainties in the final velocity model, i.e. how well-resolved are the different parts of the model. This is done by estimating the degree of dependence of the obtained solution on the initial starting model, as well as to estimate uncertainties, via Monte Carlo analysis. The method involves a number of inversions with a variety of initial models using travel time picks with random errors applied. If all the Monte Carlo realizations have the same probability and if the initial models cover the full region of non-null probability within the space of parameters, the standard deviation of the obtained solutions can be interpreted as a measure of the final model parameters uncertainty. The third issue concerns evaluating the trade-off between depth and velocity parameters linked to the reflected phase travel time inversion and depending on the source-receiver geometry. A conventional method to estimate the degree of velocity-depth ambiguity is to perform sensitivity tests, such as checkerboard tests analysis. This procedure consists of using synthetic anomalies of various sizes at specific places in the models to evaluate at what point these anomalies are well-resolved by the travel time inversion.

\subsection{Model construction and parameterization}

In order to take into account the issues detailed above, the inversion is conducted using a three step approach on each of the three profiles: (1) Estimation of the 1D reference velocity model; (2) generation of a set of 100 1D Monte Carlo starting models; and (3) iterative inversion of all the starting models. This approach is similar to that in [22] (See Fig. 5 in [23] for more details).

The main difference between our and Sallarès et al. [23] approach is that we adopt as final velocity model the best result of all the Monte Carlo realizations, characterized by the best RMS- $\chi^{2}$ couple (Fig. 5), rather than the average of all the inversion models. The velocity features modelled along each 
profile are similar in both the final best-fitting models (Fig. 5) and the mean final models derived from the Monte Carlo approach (Fig. 6-a1, 6-b1, 6-c1) but they are smoothed in the latter.

\subsection{Resolution and accuracy}

\subsubsection{Model parameter uncertainties}

The derivative weight sum (DWS, Fig. 6) [24], allows a concise representation of the ray coverage in the best final model (Fig. 5). However, no quantitative measurement concerning the resolution and accuracy of the model can be associated with this type of representation. The mean deviations of velocity and depth parameters from each Monte Carlo ensemble averaged can be interpreted as a measure of the models uncertainties and therefore used to estimate the robustness of our iterative scheme (Fig. 6), which correlates well with the ray coverage imprint (DWS).

Along profile SIS-4 (Fig. 6-b2 and 6-b3), the $>10 \mathrm{~km}$ OBS spacing seaward from the trench can be associated with a lack of short offset refractions and consequently to a larger uncertainty in the upper part of the oceanic crust (down to $7 \mathrm{~km}$ depth). Beyond 100-km distance, only refractions sample the lower part of the model so it cannot be constrained properly between 15 and $22 \mathrm{~km}$ depth.

Along profile SAL-2 (Fig. 6-c2 and 6-c3), the amplitude of arrivals recorded by OBS deployed on the continental margin becomes rapidly weak due to a thick sedimentary cover, so no clear PmP or deep refracted phase can be identified (Fig. 4, OBS 57). Rays poorly sample the model, from $90 \mathrm{~km}$ to the landward end of the line, and consequently the Moho depth and seismic velocities are poorly constrained in this area beneath $14 \mathrm{~km}$ depth.

Along profile SAL-6 (Fig. 6-a2 and 6-a3), the part of the model located between 50 and $70 \mathrm{~km}$ distance and including the lower part of the continental margin (below $10 \mathrm{~km} \mathrm{depth}$ ) and the subducting oceanic plate (up to $15 \mathrm{~km}$ depth) shows the largest velocity uncertainties $(0.2-0.25 \mathrm{~km} / \mathrm{s}$ ). Absolute velocities are not well constrained there. In this zone the DWS shows a lack in ray coverage associated with the shadow zone observed on several record sections (Fig. 2, OBH 116 and OBS 121). This shadow zone appears as a thick low velocity zone that encloses the lower part of the margin and the inter-plate contact zone in both the best fitting model (Fig. 5a) and the final averaged Monte Carlo model (Fig. 6-a1). The 100 2D final models set linked to the Monte Carlo analysis shows that the low velocity zone occurs systematically and independently of the initial velocity model considered. Checkerboard tests will help to estimate the resolvability of this low velocity zone.

\subsubsection{Checkerboard Tests}

A number of checkerboard tests (Fig. 7) has been performed in order to determine the size and amplitude of synthetic velocity anomalies resolved in different parts of the velocity models.

Along all profiles, the shape of the velocity anomalies is well recovered beneath the OBS network $(\leq 10 \mathrm{~km}$ spacing) and only a few small artefacts $(<0.2 \mathrm{~km} / \mathrm{s})$ near the crust-mantle boundary interface are observed. The differences are especially significant in profile SIS-4, in agreement with the sparser acquisition geometry and the less clear PmP and Pn phases recorded along this line, which affect the resolvability of the deep parts of the model (Fig. 7-b). Beneath zones where OBS are more than $15 \mathrm{~km}$ spaced, the pattern of velocity anomalies spreads in the direction of the mean ray-paths (Fig. 7-c2), and velocity artefacts are larger and higher $(0.2-0.4 \mathrm{~km} / \mathrm{s} ;$ Fig. $7-\mathrm{c} 2)$.

Along profile SAL-6, synthetic tests enable checking of the resolvability of the low velocity zone observed in both the best fitting model and the mean final model. The location and amplitude of velocity anomalies are reasonably well recovered within model uncertainty limits (Fig. 7-a2), indicating that the experiment geometry and data set allow a distinction between positive and negative variations at 6 to $17 \mathrm{~km}$ depth (Fig. 7-a2). The sensitivity of the data is therefore considered sufficient to resolve structures with size and amplitudes similar to the low velocity zone at this depth range implying that the low-velocity zone observed in the final models is not an artefact linked to the inversion procedure; even if the absolute value of velocity in this area is poorly constrained by the data set. 


\subsection{Results of tomographic inversion}

The tomographic inversion of travel times provides three $2 \mathrm{D}$ velocity models across the Ecuador convergent margin and the geometry of the Moho of the Nazca plate (Fig. 5).

Since there is no clear reflector separating the overriding margin from the oceanic subducting plate in the wide-angle seismic data, except along profile SIS-4 [25], we have digitized and converted to depth the inter-plate contact reflectors observed along coincident available MCS sections [4, 26-28]. The top of the subducting plate and the decollement, which mark respectively the base and the top of the subduction channel, are displayed as well as several major faults affecting the margin (Fig. 5). Only long-wavelength velocity anomalies are determined from travel time inversion and so it is likely that velocity in the subduction channel is not properly calculated. Consequently the thickness of the subduction channel observed in the tomographic models must be considered as an upperbound. Nevertheless, the comparison of wide-angle seismic models and MCS data enables the inter-plate contact in the velocity model to be located, helping to correlate and interpret velocity structures.

The uncertainty on the Moho depth is $\pm 1 \mathrm{~km}$ in the better-constrained central part of the model (Fig. 6). The crust-mantle transition is marked by a transition from crustal velocities $(<7 \mathrm{~km} / \mathrm{s})$ to mantle velocities $(7.5$ to $8.0 \mathrm{~km} / \mathrm{s})$. The agreement between the velocity transition and the Moho location is quite good in the central part of the model, where both parameters are well constrained according to the outcome of the uncertainty analysis. The dip of the subducting plate is estimated from the dip of the Moho along the different profiles, which is consistent with the dip of the top of the oceanic crust derived from MCS data (Fig. 5, table 4).

\section{Interpretation}

The tomographic models are not split into discrete layers. Nevertheless, to support the geological interpretation of the models, several model bodies or layers are differentiated based mainly on the velocities.

Along profile SAL-6 the base of the sedimentary cover inferred from the coincident MCS profile SIS44 (Fig. 8) correspond to velocities ranging from 3.5 to $4.0 \mathrm{~km} / \mathrm{s}$. At $4 \mathrm{~km}$ depth seismic velocities reach $3.6 \mathrm{~km} / \mathrm{s}$ for sands (30\% porosity) or marine shales [29]. In this paper, velocities lower than $3.5 \mathrm{~km} / \mathrm{s}$ are assumed to represent sedimentary rocks. Based on this assumption it is likely that the thickness of the sedimentary cover is underestimated because at depth velocities in highly compacted sediments are likely to exceed $3.5 \mathrm{~km} / \mathrm{s}$.

The margin basement displays velocities ranging from 3.5 to $5.5 \mathrm{~km} / \mathrm{s}$ along profile SAL-2 but velocities reach $6.2 \mathrm{~km} / \mathrm{s}$ at depth along profiles SAL-6 and SIS-4. These differences will be discussed in the next sections. The structure of the oceanic crust is discussed using a classical 3 layer scheme: oceanic layer 1 consisting of sediments with velocities lower than $3.5 \mathrm{~km} / \mathrm{s}$; oceanic layer 2 (ol2) characterized by velocities ranging from 3.5 to $6.5 \mathrm{~km} / \mathrm{s}$ and a high vertical velocity gradient and oceanic layer 3 (ol3) characterized by velocities higher than $6.5 \mathrm{~km} / \mathrm{s}$, its base defined by the Moho discontinuity.

According to the velocity models, we find considerable contrasts in structure, morphology, and sedimentary cover for both plates. We propose a zonation of the South Colombia-Ecuador convergent margin into three contrasted areas (table 4, Fig. 1): the north zone $\left(2^{\circ} \mathrm{N}-1^{\circ} \mathrm{N}\right)$, the central zone $\left(1^{\circ} \mathrm{N}-\right.$ $\left.2.5^{\circ} \mathrm{S}\right)$ and the south zone $\left(2.5^{\circ}-3.5^{\circ} \mathrm{S}\right)$.

\subsection{The North Zone : Profile SAL-6 (North Ecuador, $2^{\circ} \mathrm{N}-1^{\circ} \mathrm{N}$ )}

Along profile SAL-6, the velocity structure of the oceanic crust is well constrained from 10 to 40 $\mathrm{km}$ distance because of the 7 OBS located west of the trench (Fig. 5a). A $\sim 1.5$ to $2.0 \mathrm{~km}$ thick sedimentary cover $\left(\mathrm{V}_{\mathrm{p}}<3.5 \mathrm{~km} / \mathrm{s}\right)$ overlays oceanic layer 2 characterized by a large vertical velocity gradient, ranging from $3.5 \mathrm{~km} / \mathrm{s}$ at $\sim 5 \mathrm{~km}$ depth to $6.5 \mathrm{~km} / \mathrm{s}$ at $\sim 7 \mathrm{~km}$ depth. The small velocity gradient in the lower part of the oceanic crust $\left(\mathrm{V}_{\mathrm{p}}\right.$ from 6.5 to $\left.7.2 \mathrm{~km} / \mathrm{s}\right)$ is in good agreement with average oceanic layer 3 velocities [30]. The Moho is 10 to $11 \mathrm{~km}$ deep, leading to a 6.0 to $7.0 \mathrm{~km}$ thick igneous oceanic crust with an ol $2 / \mathrm{ol} 3$ thickness ratio of $\sim 0.59$. 
The velocity structure is consistent with "normal" oceanic crust showing no evidence of hotspot influence (e.g. [31]). The hypothesis suggesting a continuation of the Cocos-Malpelo Ridge east of the Yaquina Graben, between $2^{\circ} \mathrm{N}$ and $4^{\circ} \mathrm{N}$ [3], is not supported by our dataset.

East of the trench (distance $50-90 \mathrm{~km}$, Fig. $5 \mathrm{a}$ ), the Moho dips at $8.0^{\circ} \pm 0.5^{\circ}$. The base of the crust can be followed landward for a distance of 80-90 km with a good accuracy (Fig. 5a). Seismic velocities immediately above the Moho remain constant at around 7.0-7.5 km/s even if they are likely overestimated due the tomographic approach used. On the contrary, the velocity increases rapidly beneath the MCS reflector marking the top of the subducting oceanic crust (black dots, Fig. 5a). Its velocity increases from $5.0 \mathrm{~km} / \mathrm{s}$ at $55-\mathrm{km}$ to $6.0 \mathrm{~km} / \mathrm{s}$ at $95-\mathrm{km}$ distance in the down-dip direction, which possibly indicates modifications of the upper part of the oceanic plate during its burial.

- The sedimentary layers observed along MCS line SIS-44 (Fig. 8) are consistent with velocities lower than $3.5 \mathrm{~km} / \mathrm{s}$ modelled along the coincident wide-angle seismic line SAL-6 (Fig. 5a). The trench shows a 2 to $3 \mathrm{~km}$ thick sedimentary infill along the north Ecuador margin. This estimate is consistent with previous studies [26-28] along the south Colombia margin, indicating that the trench infill is probably due to recent and massive turbiditic intakes, via canyons, in association with hemipelagic sedimentation.

The continental slope immediately east of the trench is covered by $2.0-3.5 \mathrm{~km}$ thick sedimentary deposit. This correlates with a small, probably ancient, accretionary prism which has been described in this area using MCS data (Fig. 8) [27, 28].

On the continental margin, the thickness of the sedimentary cover is quite uniform around $\sim 2.5 \mathrm{~km}$ on average. Two sedimentary basins lie on the fore-arc (55-90-km and 90-125-km distance, Fig. 5a), and the sedimentary basin becomes thinner at the front of the margin.

The continental platform is characterized by a $\sim 600 \mathrm{~m}$ deep and $\sim 90 \mathrm{~km}$ wide morphological reentrant limited landward by a subsiding coastal area [19]. The subsidence of the continental platform is supported by the presence of the $2-3 \mathrm{~km}$ thick sedimentary basins covering the margin basement. Correlations with on-land drills made in the fore-arc basins on top of the margin [32] suggest a Palaeogene to Neogene calcareous, clay and sand origin for this sedimentary infill (e.g. [15]).

- The margin basement is characterized by velocities ranging from 5.4 to $6.2 \mathrm{~km} / \mathrm{s}$ (Fig. 9) that occupies a large part of the deep margin, and can be followed from $\sim 35 \mathrm{~km}$ east of the trench to the coast at $\sim 7 \mathrm{~km}$ depth (see table 5). The highest basement velocities $(\sim 6.2 \mathrm{~km} / \mathrm{s})$ are reached at $50-\mathrm{km}$ distance from the trench, at $\sim 10 \mathrm{~km}$ depth.

- The reflector interpreted from the MCS data (Fig. 8) as a major splay fault dipping to the east [27] marks the top of a large low velocity zone inferred from our dataset (Fig. 5a). It clearly soles out at the inter-plate boundary at 13-14 km depth (45 km from the trench), and bounds the westward limit of the "high velocity" $\left(\mathrm{V}_{\mathrm{p}} \geq 6.0 \mathrm{~km} / \mathrm{s}\right)$ upper plate basement. The seaward section of this system forms in fact a large low velocity zone and appears significantly disturbed at the deformation front (Fig. 8).

\subsection{The Central Zone: profile SIS-4 (Carnegie Ridge, $1^{\circ} \mathrm{N}-2.5^{\circ} \mathrm{S}$ )}

The final velocity model we obtain along profile SIS-4, located on the southern flank of the CR, is in agreement with the layered model based on the forward modelling of the same dataset [25] but exhibits some differences.

The oceanic crust velocity structure is followed up to $90-\mathrm{km}$ westward from the trench (Fig. $5 \mathrm{~b}$ ). The total thickness of the crust is $\sim 15 \mathrm{~km}$ here, based on the Moho location obtained from PmP travel times inversion (15 to $18 \mathrm{~km}$ depth, Fig. 6-b1). ol 2 is $\sim 3.5 \mathrm{~km}$ thick, similar to that observed along SAL-6 $(\sim 3 \mathrm{~km})$ whereas ol3 is $10 \mathrm{~km}$ thick, two fold the thickness of ol3 beneath line SAL-6.

A travel time tomography analysis along a wide-angle line extending from the top of CR to the oceanic basin across its northern flank [33] (see location of refraction line in Fig. 1) reveals that the maximum crustal thickness beneath the crest of the ridge is $19 \mathrm{~km}(\sim 100 \mathrm{~km}$ north of profile SIS-4) with a similar velocity structure. If we compare this profile with profile SIS-4, it appears that the thickness of ol2 remains uniform through CR whereas the thickness of ol3 increases with increasing total thickness. 
The crustal thickening is dominated by ol3 thickening (ol2/ol3 thickness ratio $<0.3$ ), which confirms that the CR has originated from the interaction between the GHS and the Galapagos spreading centre [3, 34-36], generating increased melt production within the mantle source.

Due to the scarcity of data, the model is not well constrained east of $130-\mathrm{km}$ distance. Reflection from the top of the oceanic crust along coincident MCS lines and modelling of intra-crustal wide-angle reflections provide a dip ranging from $4^{\circ}$ beneath the slope to $\sim 10^{\circ}$ dip beneath the Ecuadorian coast at $\sim 15 \mathrm{~km}$ depth [25]. Deeper and farther inland the Wadati-Benioff zone dip varies between $35^{\circ}$ and $25^{\circ}$ between $1^{\circ} \mathrm{N}$ and $1.5^{\circ} \mathrm{S}$, reaching at least a $\sim 150 \mathrm{~km}$ depth in the north and $\sim 200 \mathrm{~km}$ depth in the south [37].

On the CR and in the oceanic basin south of it, the sedimentary cover and trench fill are as thin as 0.5 to $1.0 \mathrm{~km}$ assuming a velocity lower than $3.5 \mathrm{~km} / \mathrm{s}$. The lack of sediments on top of the CR and on its southern flank could be explained by the prominent topographic feature of the CR, which acts as a barrier and influences marine current trajectories, sedimentary flux, deposition [4, 5, 38, 39], and the erosive power of strong marine currents.

Similarly, the continental shelf shows a very thin sedimentary cover (less than $\sim 1 \mathrm{~km}$ thick), which confirms that no subduction-accretion occurs along this segment $[4,5,38,39]$. The coastal area facing the CR has been uplifted as indicated by Quaternary marine terraces exposed at 200-300 m elevation [17]. As a consequence, no rivers coming from the Andes cross the Coastal Cordillera and precludes sediment influx towards the trench $[4,5,38,39]$.

At the southern flank of the CR, the margin wedge consist of a body with velocities that reach 5.7 $\mathrm{km} / \mathrm{s}$ at $30 \mathrm{~km}$ east of the trench and $6.2 \mathrm{~km} / \mathrm{s}$ at $40 \mathrm{~km}$ east of the trench, at $\sim 5 \mathrm{~km}$ depth (table 5). These velocities are higher than velocities described in similar context and will be discussed in the next section.

\subsection{The South Zone: Profile SAL-2 (Gulf of Guayaquil, $2.5^{\circ} \mathrm{S}-3.5^{\circ} \mathrm{S}$ )}

Along profile SAL-2 the structure of the oceanic plate is followed up to $\sim 47 \mathrm{~km}$ westward from the trench. Seaward from the trench, the Moho is located at $\sim 11.5 \mathrm{~km}$ depth (Fig. 5c). The crust of the oceanic plate is $\sim 8 \mathrm{~km}$ thick, only slightly thicker than along the northern line (SAL-6). Major differences are observable in the very thin sedimentary cover which has a maximum thickness of $\sim 0.5$ $\mathrm{km}$ (for velocities $<3.5 \mathrm{~km} / \mathrm{s}$ ), a thinner ol2 $(\sim 2.5 \mathrm{~km}$ thick) with velocities from $\sim 3.5$ to $6.0 \mathrm{~km} / \mathrm{s}$, and a $5 \mathrm{~km}$ thick ol3 $\left(\mathrm{V}_{\mathrm{p}}\right.$ rising from 6.2 to $\left.7.0 \mathrm{~km} / \mathrm{s}\right)$. Despite a velocity structure close to normal oceanic crust, the low ol2/ol3 thickness ratio $(\sim 0.40)$ and the slight thickening of ol3 ( 1 km thicker) suggest the crust underwent some influence of the GHS activity during its emplacement [30].

East of the trench, the oceanic Moho dips at $5.0^{\circ} \pm 0.5^{\circ}$. The thickness of the subducting oceanic crust deduced from depth-migrated MCS reflectors is $6.5-7.0 \mathrm{~km}$. The velocity structure of ol2 and ol3 can be followed from the trench to $\sim 95-\mathrm{km}$ distance and is characterized by isovelocity curves parallel to the Moho at the base of the crust. The velocity at the top of the oceanic crust increases slightly during the down-warping process (from $4 \mathrm{~km} / \mathrm{s}$ at $4 \mathrm{~km}$ depth to $5.5 \mathrm{~km} / \mathrm{s}$ at $13 \mathrm{~km}$ depth), similar to our observations along SAL-6.

The tomographic model shows the margin sedimentary cover $\left(\mathrm{V}_{\mathrm{p}} \leq 3.5 \mathrm{~km} / \mathrm{s}\right)$ progressively thickening from $\sim 1 \mathrm{~km}$ at margin front to up to $7 \mathrm{~km}$ in the inner part of the GG (between $50-\mathrm{km}$ to $135-\mathrm{km}$ distance). Because of the compaction processes that likely occur at depth, it is possible that velocities higher than $3.5 \mathrm{~km} / \mathrm{s}$ characterize the lower part of the sedimentary pile. Consequently, the sedimentary thickness in the basins might be underestimated but this will not affect our interpretation. Interpretation of industrial multichannel seismic profiles show that the continental slope (distance 50$115 \mathrm{~km}$, Fig. 5) is affected by a series of N-S trending listric normal faults controlled by the subduction processes $[16,40]$. On the contrary, the continental platform (east of 115-km distance along profile SAL-2) is mainly controlled by the northward tectonic escape of the North Andean Block since the Pleistocene. But both segments seem to have been subsiding zones since the Miocene $[16,40]$. According to this interpretation, the up to 7-km thick eastern basin located on the platform (distance 105-145-km) may be related both to subduction-erosion processes (i.e. tectonic erosion of the upper plate's underside) since the Miocene, and to the N-S extensive regime affecting the GG 
since the Pleistocene. Whereas the sedimentary basin lying on the upper part of the slope (distance 80$110-\mathrm{km}$, Fig. 5c) is more likely to be related to tectonic erosion at the base of the margin $[16,40]$.

Westward, a thin sedimentary cover and infill characterize the deformation front and the trench area. Thus, the important sediment influx coming from the Andes does not seem to reach the trench, but is predominantly trapped in the large sedimentary basins lying on the continental platform and on the slope, in the region of greater subsidence. At the deformation front, a thinner sedimentary cover is associated with a progressive uplift of the margin basement possibly indicating weak compressive deformation expressed at the wedge [26].

The subsidence of the margin fore-arc in front of the GG, made evident by the thick sedimentary basin, supports a concept of large scale tectonic erosion. In such a context, the strong dip of the margin front appears as a consequence of frontal erosion. Moreover, several MCS sections acquired in this area show basal erosion associated with the subduction of down going seamounts carried by the oceanic plate [41].

In this zone, seismic velocities ranging from $\sim 3.5$ to $5.2 \mathrm{~km} / \mathrm{s}$ characterize the basement of the margin. Here, velocities in the margin wedge are lower than the ones described along northern and central Ecuador profiles (Fig. 5, table 5). From the trench to $80-\mathrm{km}$ distance the continental shelf shows a progressive uplift of this layer up to $1 \mathrm{~km}$ below the seafloor. At $100-\mathrm{km}$ distance another high point of this layer reaches up to $2.5 \mathrm{~km}$ beneath the seafloor. It separates the upper slope from the eastern basin. Velocities obtained for the margin substratum, $60 \mathrm{~km}$ east of the trench, are as low as $5.2 \mathrm{~km} / \mathrm{s}$ at $10 \mathrm{~km}$ depth, with a constant vertical gradient of $\sim 0.2 \mathrm{~km} / \mathrm{s} / \mathrm{km}$ (Fig. 9).

The GG roughly separates the northern fore-arc units (North Andean Block) made of oceanic terranes from the southern fore-arc units of continental composition $[42,43]$ but the limit between oceanic and continental basement is not precisely known. The Piñon formation outcrops on-land in northern Peru and possibly extends off-shore beneath Banco Peru (Fig. 1) [9].

Shadow zones appear along several wide-angle seismic sections (e.g., Fig. 4). They cannot be modelled from inversion of first arrival travel times alone but possibly denote a low velocity subduction channel that supports the basal erosion of the margin's underside. In fact, the resulting debris dragged along the inter-plate contact zone generally create a small velocity inversion which gradually disappears with the down-going process(e.g., [41]).

\section{Discussion}

In this study, we corroborate that the Moho beneath the CR presents a strong dissymmetry with a sharp transition from the thick crust associated with volcanic ridges to normal oceanic crust associated with the oceanic basin beneath the northern flank [33] (whereas the crust of the ridge thins progressively southward [3, 33]). We show that the oceanic crust south of the CR southern flank (profile SAL-2) is slightly thicker than "normal" oceanic crust probably because of the influence of the GHS, that is outlined by numerous seamounts described from multibeam bathymetric data (Fig. 1) [41]. This is consistent with the present-day thermal anomaly associated with the GHS that influences the generation of new oceanic crust within at least $350 \mathrm{~km}$ radius $[33,44]$.

To the north (profile SAL-6), we find "normal" oceanic crust thickness which precludes the continuation of the Cocos-Malpelo Ridge east of the Yaquina Graben [33].

The basement wedge offshore central Ecuador near La Plata Island exhibits higher velocities at similar distance from the trench than any other well-constrained margin wedge (table 5). Margins with similar velocities are the Nicoya Peninsula [45] consisting of a well-known ophiolitic complex, the Chile margin offshore Antofagasta where the basement consists of basaltic to andesitic rocks [46], the Shumagin Islands margin wedge which consists of interstratified volcanic and sedimentary rocks [47] and the Cascadia margin offshore Oregon associated with the Siletz terrane of oceanic origin [48-50].

The margin of Ecuador is part of the North Andean Block and mainly consists of oceanic cretaceous rocks outcropping extensively on-land and on La Plata Island immediately north of profile SIS-4 (Fig. 1). Then, the margin wedge consists undoubtedly of the same type of oceanic rocks. Furthermore, the velocities encounted in the margin basement are similar to the one determined in the upper crust of numerous oceanic plateaus like the Kerguelen Plateau [51], the Ontong Java Plateau [52], the 
Caribbean Plateau [53] or the Cocos and Carnegie ridges [23, 33] (refer to the compilation in [45] for more details).

- Velocities in the margin wedge offshore North Ecuador - South Colombia are comparable to those determined in the Cascadia margin and Eastern Nankai Trough, which include accreted oceanic fragment $[54,55]$. They are not as high as the velocities observed in front of the Carnegie ridge at the toe of the margin. Nevertheless, outcrops of oceanic rocks on-land at the border between Colombia and Ecuador, as well as on Gorgone Island less than $140 \mathrm{~km}$ north of profile SAL-6 [12-14, 56], prove a similar oceanic nature for the basement wedge which is part of the North Andean Block.

Along the Peru margin, despite rather high seismic velocities, the margin wedge consists of Palaeozoic or Precambrian foliated metamorphic rocks of continental origin [57]. Velocities in the margin wedge beneath the Gulf of Guayaquil are lower than those observed along the central and north Ecuador margin and could denote either a different nature or a higher degree of fracturing.

A progressive increase of seismic velocities in the backstop from $3.0-3.5 \mathrm{~km} / \mathrm{s}$ near the trench to $4.5-6.2 \mathrm{~km} / \mathrm{s}$ over a horizontal distance of $20 \mathrm{~km}$ is observed in all of the well-resolved model based on forward modelling or on tomographic inversion (see table 5). Velocities lower than $3.5 \mathrm{~km} / \mathrm{s}$ are most likely to represent sedimentary rocks either accreted at the margin or deriving from the continent. Low velocities observed at the margin toe are usually interpreted as associated to fracturing, or alteration processes that affect the rocks of the margin basement and increase the porosity of these rocks $[45,46,57,58]$. These processes decrease landward where the margin wedge is thicker and more mechanically resistant.

The seismic velocities obtained along profile SAL-2 for the margin basement of the GG cannot be immediately linked to accreted oceanic terranes as the GG probably represents the southern limit of the North Andean Block [40]. Velocities in the margin basement range reach 4.5 to $5.0 \mathrm{~km} / \mathrm{s}$ at $13 \mathrm{~km}$ depth. They are similar to velocities in the OSA Peninsula (Costa Rica) where the rocks outcropping are a middle mid-Eocene/Miocene melange dominated by basalt, chert, and limestone resulting from accretion of seamounts [59]. It is also comparable to the velocity structure described along the Western Nankai Trough, where the margin basement is interpreted as an old metamorphosed accretionary complex, the Shimanto Belt $[60,61]$.

So, it is not possible from seismic velocity alone to determine the nature of the basement beneath the GG. The low velocities obtained along profile SAL-2 are lower than velocities described northward in front of the Carnegie Ridge (this study) interpreted to be related to the oceanic North Andean Block. But they are also lower than velocities described in the basement of the margin off northern Peru [57] which are related to the metamorphic basement. We assume that these low velocities in the GG basement should be mainly related to a high degree of fracturing associated with the NS extension in the Gulf itself and with the erosion of the outer part of the margin [40].

- Tectonic erosion is favoured in regions where convergence rates exceed $\sim 60-\mathrm{mm} / \mathrm{yr}$ and where the sedimentary cover is $<1 \mathrm{~km}$ [62]. Rates of subduction-erosion can be computed efficiently from the offshore subsidence record and the geometry of the margin [63]. Along the margin, from Colombia to the GG, the slope of the margin is $15^{\circ}$ to $20^{\circ}$ (Fig. 1 and 5). Subsidence can be inferred by the thickness of low velocities and non-compacted sediments. The steepness of the slope, the lack of an accretionary prism except near the Colombian border, subsidence of the middle slope and of the forearc basin suggest significant erosion at the base of the overriding plate [63].

Subduction-erosion can be envisaged as being linked to strong coupling between the overriding and subducting plate, although processes like hydro-fracturing at the base of the overriding fore-arc crust are also identified as a convincing explanation for basal tectonic erosion. Fluid overpressure, finally, is thought to generate fractures in the basal region of the upper plate [63-65]. This loosens fragments that are then dragged into the subduction channel where they may undergo further downward transport [63-65].

In north Ecuador, a small accretionary prism observed at the front of the margin suggests accretion whereas the strong subsidence of the margin supports basal erosion at the deep part of the basement. The margin appears to be at the limit between subduction-accretion which is more developed northward (towards Colombia) and subduction-erosion as it has been suggested from previous studies $[4,27,28,66]$. 
At the CR, the increased buoyancy of the Nazca plate is likely to cause the observed general uplift of the coast in this area [18]. There is no evidence of subduction-accretion along this segment of the margin on the MCS data [4]. The high velocity oceanic basement, which extends westward only 30 $\mathrm{km}$ from the trench (Fig. 5b) and seems to extend beneath the whole margin, as well as the lack of fore-arc basin, do not support a basal erosion scenario. Furthermore, the MCS data reveal basal erosion related to the presence of seamounts on the subducting plate, which affects the margin south of latitude $1^{\circ} 40^{\prime} \mathrm{S}$ [41].

South of the CR, the strong subsidence of the margin, the low seismic velocity of the possibly highly fractured basement and evidence for low velocity material in the subduction channel despite the lack of sediments in the trench support an intense erosion of the margin associated with a north-south extension of the continental platform. In this area, we suggest basal erosion is related to high-pressure fluids rather than a strong coupling.

The segmentation of the margin is primarily related to the subduction of the CR that controls the sediment distribution and increases significantly the interplate coupling in the central zone. The north zone presents a well-defined sequence of 4 earthquakes rupturing the seismogenic interface during the $20^{\text {th }}$ century (Fig. 1) [67-69]. The regular shallow seismicity along the margin, based on worldwide seismic networks (Fig. 10), is concentrated immediately East of the trench mainly with thrust focal mechanisms. This supports that the subduction is partially locked north of $2^{\circ} \mathrm{S}$ as inferred from geodetic measurements and modelling [1].

The oceanic nature of the basement of the overriding plate in the Central and North Zone contributes to increase the interplate coupling because of its higher density. The contact between the top of the downgoing oceanic crust with strong material (velocities $>5 \mathrm{~km} / \mathrm{s}$ ) was interpreted as an estimate of the region of seismic onset [70]. In our case, the lack of shallow seismicity $(<20 \mathrm{~km})$ in the GG (Fig. 10 ) is consistent with the change in the velocity structure of the overriding plate and also possibly with a different process of basal erosion associated with fluid overpressure. We suggest this region is characterized by a low seismic coupling. The two large earthquakes that occurred in 1901 and 1953 are located near the northern and southern border of the GG (Fig. 10) and suggest a rapid change in seismic coupling to the north and to the south of the gulf.

\section{Conclusions}

Wide angle seismic models obtained by travel time inversion at the Ecuadorian convergent margin reveal variations in the crustal structure of the subducting Nazca plate and the overriding South American plate that strongly control the deformation of the margin and the seismic cycle :

(1) The North Zone exhibits normal oceanic crust with no evidence for the influence of the GHS. The overriding plate is characterized by a well-developed Cretaceous oceanic substratum, described onland as the Diabasico and Piñon formations, underlain by high seismic velocities $(5.5-6.2 \mathrm{~km} / \mathrm{s})$. The structure of the margin suggests it was affected by transient phases of erosion and accretion.

The inner part of the margin shows a large low velocity zone. Its upper limit correlates with a major splay fault that originates on the inter-plate contact zone and could have favoured the propagation of the 1958 great earthquake rupture [27].

(2) The Central Zone reveals an over-thickened oceanic crust (15 to $19 \mathrm{~km}$ ) beneath the CR. The Cretaceous oceanic basement is well-developed and is likely to have been uplifted beneath the margin. The buoyancy of the Nazca plate and the high density of the margin basement both contribute to an increased interplate coupling. The fore-arc shows neither evidence of subsidence nor of frontal accretion.

(3) The South Zone is characterized by a $7 \mathrm{~km}$ thick oceanic crust, which was slightly influenced by the GHS during its emplacement 20 My ago. The continental slope and the platform show clues of subsidence, possibly related to intense tectonic erosion of the upper plate's base. We suggest that the low seismic velocities described for the margin basement could be related to an intense fracturing associated with the presence of fluids and low seismic coupling. 


\section{Acknowledgements}

The French scientific party was supported by Institut de Recherche pour le Développement (IRD), Institut National des Sciences de l'Univers (INSU) and Institut Français pour l'Exploitation de la Mer (IFREMER), which provided ship time during the SISTEUR experiment. The SALIERI-2001 experiment was funded by the German Ministry of Education, Research, Science and Technology (BMBF) under project no. 03G0159A. We are also indebted to H. Andersen, master of the R/V Sonne, and its crew for their support during the SALIERI experiment and to Captain R. Davila and the crew of R/V Orion (INOCAR) from which OBS were operated during the SISTEUR experiment. During the Sisteur experiment the R/V Atalante (chief scientist Jean-Yves Collot) shot over the OBS networks. Also special thanks to Y. Hello, A. Anglade and B. Yates who successfully operated the OBS at sea and to the scientific parties of both campaigns. Finally we thank Tim Minshull for his detailed review which helped us to improve the initial version of this manuscript.

\section{References}

[1] R. Trenkamp, J.N. Kellogg, J.T. Freymueller, H.P. Mora, Wide plate margin deformation, southern Central America and northwestern South America, CASA GPS observations, Journal of South American Earth Sciences 15(2002) $157-171$.

[2] P. Lonsdale, Creation of the Cocos and Nazca plates by fission of the Farallon plate, Tectonophysics 404(2005) 237264.

[3] V. Sallares, P. Charvis, Crustal thickness constraints on the geodynamic evolution of the Galapagos Volcanic Province, Earth and Planetary Science Letters 214(2003) 545-559.

[4] J.-Y. Collot, P. Charvis, M.-A. Gutscher, S. Operto, the Sisteur scientific party, Exploring the Ecuador-Colombia active margin and inter-plate seismogenic zone, EOS 83(2002) 185,189-190.

[5] M.A. Gutsher, J. Malavieille, S. Lallemand, J.Y. Collot, Tectonic segmentation of the North Andean margin: impact of the Carnegie Ridge collision, Earth and Planetary Science Letters 168(1999) 255-270.

[6] R. Hey, Tectonic evolution of the Cocos-Nazca spreading center, Geological Society of America Bulletin 88(1977) 1404-1420.

[7] P. Lonsdale, K.D. Klitgord, Structure and tectonic history of the eastern Panama Basin, Geological Society of America Bulletin 89(1978) 981-999.

[8] E. Jaillard, S. Benitez, G.H. Mascle, Palaeogene deformations of the forearc zone of south Ecuador in relation to the geodynamic evolution, Bulletin De La Societe Geologique De France 168(1997) 403-412.

[9] G.L. Shepherd, R. Moberly, Coastal Structure of the Continental-Margin, Northwest Peru and Southwest Ecuador, Geological Society of America Memoirs 154(1981) 351-391.

[10] E. Jaillard, M. Ordonez, S. Benitez, G. Berrones, M. Jimenez, G. Montenegro, I. Zambrano, Basin development in an accretionnary, oceanic-floored fore-arc setting : southern coastal Ecuador during late Cretaceaous - late Eocene time, in: A.J. Tankard, R. Suarez, H.J. Welsink, (Eds), Petroleum Basins of South America, Volume AAPG memoire 62, 1995, pp. 615-632.

[11] C. Reynaud, E. Jaillard, H. Lapierre, M. Mamberti, G.H. Mascle, Oceanic plateau and island arcs of southwestern Ecuador: their place in the geodynamic evolution of northwestern South America, Tectonophysics 307(1999) 235254.

[12] P.J. Goosens, W.I. Rose, D. Flores, Geochemistry of tholeiites of the basic igneous complex of Northwestern South America, Geological Society of America Bulletin 88(1977) 1711-1720.

[13] J.M. Mamberti, H. Lapierre, D. Bosch, E. Jaillard, J. Hernandez, M. Polvé, The Early Cretaceous San Juan Plutonic Suite, Ecuador: A magma chamber in an oceanic plateau?, Canadian Journal of Earth Sciences 41(2004) 12371258.

[14] G.F. Marriner, D. Millward, The Petrology and Geochemistry of Cretaceous to Recent Volcanism in Colombia - the Magmatic History of an Accretionary Plate Margin, Journal of the Geological Society 141(1984) 473-486.

[15] Y. Deniaud, Enregistrement sédimentaire et structural de l'évolution géodynamique des Andes équatoriennes au cours du Néogène : étude des bassins d'avant-arc et bilans de masse, Université Joseph Fourier, 2000.

[16] C. Witt, J. Bourgois, F. Michaud, M. Ordonez, N. Jimenez, M. Sosson, Development of the Gulf of Guayaquil (Ecuador) during the Quaternary as an effect of the North Andean block tectonic escape, Tectonics 25(2006). 
[17] T. De Vries, The geology of late Cenozoic marine terraces (tablazos) in northwestern Peru, Journal of South American Earth Sciences 1(1988) 121-136.

[18] K. Pedoja, J.F. Dumont, M. Lamothe, L. Ortlieb, J.Y. Collot, B. Ghaleb, M. Auclair, V. Alvarez, B. Labrousse, PlioQuaternary uplift of the Manta Peninsula and La Plata Island and the subduction of the Carnegie Ridge, central coast of Ecuador, Journal of South American Earth Sciences 22(2006) 1-21.

[19] J.F. Dumont, E. Santana, F. Valdez, J.P. Tihay, P. Usselmann, D. Iturralde, E. Navarette, Fan beheading and drainage diversion as evidence of a 3200-2800 BP earthquake event in the Esmeraldas-Tumaco seismic zone: A case study for the effects of great subduction earthquakes, Geomorphology 74(2006) 100-123.

[20] E.R. Flueh, J. Bialas, P. Charvis, Cruise Report SO159 - Salieri, Geomar, Kiel, 2001, p. 256.

[21] Y. Nakamura, J. Garmany, Development of upgraded ocean bottom seismograph, University of Texas Institute for Geophysics Technical Report, 1991, p. 45.

[22] J. Korenaga, W.S. Holbrook, G.M. Kent, P.B. Kelemen, R.S. Detrick, H.C. Larsen, J.R. Hopper, T. Dahl-Jensen, Crustal structure of the southeast Greenland margin from joint refraction and reflection seismic tomography, Journal of Geophysical Research-Solid Earth 105(2000) 21591-21614.

[23] V. Sallares, P. Charvis, E.R. Flueh, J. Bialas, Seismic structure of Cocos and Malpelo Volcanic Ridges and implications for hot spot-ridge interaction, Journal of Geophysical Research-Solid Earth 108(2003).

[24] D.R. Toomey, G.R. Foulger, Tomographic Inversion of Local Earthquake Data from the Hengill-Grensdalur Central Volcano Complex, Iceland, Journal of Geophysical Research-Solid Earth and Planets 94(1989) 17497-17510.

[25] D. Graindorge, A. Calahorrano, P. Charvis, J.-Y. Collot, N. Bethoux, Seismic evidences of Carnegie Ridge subduction and the Ecuadorian margin structure at $1.4^{\circ} \mathrm{S}$, Geophysical Research Letters 31(2004).

[26] A. Calahorrano, Structure de la marge du Golfe de Guayaquil (Equateur) et propriétés physiques du chenal de subduction à partir de données de sismique marine réflexion et réfraction, Thèse de Doctorat, Université Pierre et Marie Curie (Paris VI), 2005.

[27] J.-Y. Collot, B. Marcaillou, F. Sage, F. Michaud, W. Agudelo, P. Charvis, D. Graindorge, M.A. Gutscher, G. Spence, Are rupture zone limits of great subduction earthquakes controlled by upper plate structures? Evidences from Multichannel seismic reflection data acquired across the northern Ecuador-southwest Colombia margin, Journal of Geophysical Research 109(2004) 14 pages.

[28] B. Marcaillou, Régimes tectoniques et thermiques de la marge Nord Equateur - Sud Colombie $\left(0^{\circ}-3.5^{\circ} \mathrm{N}\right)-$ Implications sur la sismogenèse, Thèse de Doctorat, Université Pierre et Marie Curie (Paris VI), 2003.

[29] P. Japsen, T. Mukerji, G. Mavko, Constraints on velocity-depth trends from rock physics models, Geophysical Prospecting 55(2007) 135-154.

[30] C.Z. Mutter, J.C. Mutter, Variations in thickness of layer 3 dominate oceanic crustal structure, Earth and Planetary Science Letters 117(1993) 295-317.

[31] R.S. White, D. $\mathrm{M}^{\mathrm{c}}$ Kenzie, R.K. O'Nions, Oceanic crustal thickness from seismic measurements and rare earth element inversions, Journal of Geophysical Research 97(1992) 19683-19715.

[32] N.P. Mountney, G.K. Westbrook, Quantitative analysis of Miocene to Recent forearc basin evolution along the Colombian convergent margin, Basin Research 9(1997) 177-196.

[33] V. Sallares, P. Charvis, E.R. Flueh, J. Bialas, Seismic structure of the Carnegie ridge and the nature of the Galapagos hotspot, Geophysical Journal International 161(2005) 763-788.

[34] U. Barckhausen, C.R. Ranero, R. von Huene, S.C. Cande, H.A. Roeser, Revised tectonic boundaries in the Cocos Plate off Costa Rica: Implications for the segmentation of the convergent margin and for plate tectonic models, Journal of Geophysical Research-Solid Earth 106(2001) 19207-19220.

[35] R. Hey, G.L. Johnson, A. Lowrie, Recent Plate Motions in Galapagos Area, Geological Society of America Bulletin 88(1977) 1385-1403.

[36] D.S. Wilson, R.N. Hey, History of Rift Propagation and Magnetization Intensity for the Cocos-Nazca Spreading Center, Journal of Geophysical Research-Solid Earth 100(1995) 10041-10056.

[37] B. Guillier, J.L. Chatelain, E. Jaillard, H. Yepes, G. Poupinet, J.F. Fels, Seismological evidence on the geometry of the orogenic system in central-northern Ecuador (South America), Geophysical Research Letters 28(2001) 3749-3752.

[38] F. Michaud, A. Chabert, J.-Y. Collot, V. Sallarès, E.R. Flueh, P. Charvis, D. Graindorge, M.-A. Gustcher, J. Bialas, Fields of multi-kilometer scale sub-circular depressions in the Carnegie ridge sedimentary blanket : effect of underwater carbonate dissolution?, Marine Geology 216(2005) 205-219.

[39] A.C. Mix, R. Tiedemann, P. Blum, shipboard scientists, (Eds), Southeast Pacific Paleoceanographic Transects Sites 1232 - 1242, ODP Leg 202, 2002. 
[40] C. Witt, Constraints on the tectonic evolution of the North Andean Block trailing edge: evolution of the Gulf of Guayaquil-Tumbes Basin and the intermountain basins of the Central Ecuadorian Andes, Thèse de Doctorat, Université Pierre et Marie Curie, 2007.

[41] F. Sage, J.Y. Collot, C.R. Ranero, Interplate patchiness and subduction-erosion mechanisms: Evidence from depthmigrated seismic images at the central Ecuador convergent margin, Geology 34(2006) 997-1000.

[42] E. Jaillard, G. Herail, T. Monfret, G. Worner, Preface - Andean geodynamics: main issues and contributions from the 4th ISAG, Gottingen, Tectonophysics 345(2002) 1-15.

[43] T. Mourier, C. Laj, F. Megard, P. Roperch, P. Mitouard, A.F. Medrano, An Accreted Continental Terrane in Northwestern Peru, Earth and Planetary Science Letters 88(1988) 182-192.

[44] J.P. Canales, G. Ito, R.S. Detrick, J. Sinton, Crustal thickness along the western Galapagos Spreading Center and the compensation of the Galapagos hotspot swell, Earth and Planetary Science Letters 203(2002) 311-327.

[45] G.L. Christeson, K.D. McIntosh, T.H. Shipley, E.R. Flueh, H. Goedde, Structure of the Costa Rica convergent margin, offshore Nicoya Peninsula, Journal of Geophysical Research-Solid Earth 104(1999) 25443-25468.

[46] V. Sallares, C.R. Ranero, Structure and tectonics of the erosional convergent margin off Antofagasta, north Chile (23 degrees 30 ' S), Journal of Geophysical Research-Solid Earth 110(2005).

[47] S.D. Lewis, J.W. Ladd, T.R. Bruns, Structural Development of an Accretionary Prism by Thrust and Strike-Slip Faulting - Shumagin Region, Aleutian Trench, Geological Society of America Bulletin 100(1988) 767-\&.

[48] M. Gerdom, A.M. Trehu, E.R. Flueh, D. Klaeschen, The continental margin off Oregon from seismic investigations, Tectonophysics 329(2000) 79-97.

[49] D. Graindorge, G. Spence, P. Charvis, J.-Y. Collot, R. Hyndman, A. Trehu, Crustal structure beneath the Strait of Juan de Fuca and Southern Vancouver Island from seismic gravity analyses, Journal of Geophysical Research 108(2003) 2484.

[50] A.M. Trehu, I. Asudeh, T.M. Brocher, J.H. Luetgert, W.D. Mooney, J.L. Nabelek, Y. Nakamura, Crustal Architecture of the Cascadia Fore-Arc, Science 266(1994) 237-243.

[51] P. Charvis, M. Recq, S. Operto, D. Brefort, Deep structure of the Kerguelen-Heard Plateau and hot spot-related activity, Geophysical Journal International 122(1995) 899-924.

[52] T.P. Gladczenko, M.F. Coffin, O. Eldholm, Crustal structure of the Ontong Java Plateau: Modeling of new gravity and existing seismic data, Journal of Geophysical Research-Solid Earth 102(1997) 22711-22729.

[53] V. Sallares, J.J. Dañobeitia, E.R. Flueh, G. Leandro, Seismic velocity structure across the middle American landbridge in northern Costa Rica, Geodynamics 27(1999) 327-344.

[54] J.X. Dessa, S. Operto, S. Kodaira, A. Nakanishi, G. Pascal, K. Uhira, Y. Kaneda, Deep seismic imaging of the eastern Nankai trough, Japan, from multifold ocean bottom seismometer data by combined travel time tomography and prestack depth migration, Journal of Geophysical Research-Solid Earth 109(2004).

[55] A. Nakanishi, H. Shiobara, R. Hino, S. Kodaira, T. Kanazawa, H. Shimamura, Detailed subduction structure across the eastern Nankai Trough obtained from ocean bottom seismographic profiles, Journal of Geophysical Research-Solid Earth 103(1998) 27151-27168.

[56] A. Nivia, Geochemistry and origin of the amaime and volcanic sequences southwestern Colombia, Unpublished M. Phil. thesis, University of Leicester, 1987.

[57] A. Krabbenhoft, J. Bialas, H. Kopp, N. Kukowski, C. Hubscher, Crustal structure of the Peruvian continental margin from wide-angle seismic studies, Geophysical Journal International 159(2004) 749-764.

[58] C.R. Ranero, R. von Huene, Subduction erosion along the Middle America convergent margin, Nature 404(2000) 748752.

[59] P. Vannucchi, D.M. Fisher, S. Bier, T.W. Gardner, From seamount accretion to tectonic erosion: Formation of Osa Melange and the effects of Cocos Ridge subduction in southern Costa Rica, Tectonics 25(2006).

[60] S. Kodaira, N. Takahashi, J.O. Park, K. Mochizuki, M. Shinohara, S. Kimura, Western Nankai Trough seismogenic zone: Results from a wide-angle ocean bottom seismic survey, Journal of Geophysical Research-Solid Earth 105(2000) 5887-5905.

[61] N. Takahashi, S. Kodaira, A. Nakanishi, J.O. Park, S. Miura, T. Tsuru, Y. Kaneda, K. Suyehiro, H. Kinoshita, N. Hirata, T. Iwasaki, Seismic structure of western end of the Nankai trough seismogenic zone, Journal of Geophysical Research-Solid Earth 107(2002).

[62] P. Clift, P. Vannucchi, Controls on tectonic accretion versus erosion in subduction zones: Implications for the origin and recycling of the continental crust, Reviews of Geophysics 42(2004).

[63] N. Kukowski, O. Oncken, Subduction erosion - the "normal" mode of fore-arc material transfer along the Chilean margin?, in: O. Oncken, G. Chong, G. Franz, P. Giese, H.J. Götze, V.A. Ramos, M.R. Strecker, P. Wigger, (Eds), 
The Andes - active subduction orogeny, Frontiers in Earth Science Series 1, Springer-Verlag, Berlin Heidelberg New York, 2006, pp. 217-236.

[64] S.E. Lallemand, P. Schnurle, J. Malavieille, Coulomb Theory Applied to Accretionary and Nonaccretionary Wedges Possible Causes for Tectonic Erosion and or Frontal Accretion, Journal of Geophysical Research-Solid Earth 99(1994) 12033-12055.

[65] R. von Huene, C.R. Ranero, P. Vannucchi, Generic model of subduction erosion, Geology 32(2004) 913-916.

[66] M.A. Gutscher, J. Malavieille, S. Lallemand, J.Y. Collot, Tectonic segmentation of the North Andean margin: impact of the Carnegie Ridge collision, Earth and Planetary Science Letters 168(1999) 255-270.

[67] S.L. Beck, L.J. Ruff, The Rupture Process of the Great 1979 Colombia Earthquake - Evidence for the Asperity Model, Journal of Geophysical Research 89(1984) 9281-9291.

[68] H. Kanamori, K.C. McNally, Variable Rupture Mode of the Subduction Zone Along the Ecuador - Colombia Coast, Bulletin of the Seismological Society of America 72(1982) 1241-1253.

[69] C. Mendoza, J.W. Dewey, Seismicity Associated with the Great Colombia-Ecuador Earthquakes of 1942, 1958, and 1979 - Implications for Barrier Models of Earthquake Rupture, Bulletin of the Seismological Society of America 74(1984) 577-593.

[70] J.F. Pacheco, L.R. Sykes, C.H. Scholz, Nature of Seismic Coupling Along Simple Plate Boundaries of the Subduction Type, Journal of Geophysical Research-Solid Earth 98(1993) 14133-14159.

[71] W.H.F. Smith, D.T. Sandwell, Global sea floor topography from satellite altimetry and ship depth soundings, Science 277(1997) 1956-1962.

[72] A.M. Dziewonski, T.A. Chou, J.H. Woodhouse, Determination of earthquake source parameters from waveform data for studies of global and regional seismicity, Journal of Geophysical Research 86(1981) 2825-2852.

[73] Y. Nakamura, K. McIntosh, A.T. Chen, Preliminary results of a large offset seismic survey west of Hengchun Peninsula, southern Taiwan, Terrestrial Atmospheric and Oceanic Sciences 9(1998) 395-408.

[74] S. Ye, E.R. Flueh, D. Klaeschen, R. vonHuene, Crustal structure along the EDGE transect beneath the Kodiak shelf off Alaska derived from OBH seismic refraction data, Geophysical Journal International 130(1997) 283-302.

[75] E.R. Flueh, N. Vidal, C.R. Ranero, A. Hojka, R. von Huene, J. Bialas, K. Hinz, D. Cordoba, J.J. Danobeitia, C. Zelt, Seismic investigation of the continental margin off- and onshore Valparaiso, Chile, Tectonophysics 288(1998) 251263.

[76] K.D. McIntosh, Y. Nakamura, Crustal structure beneath the Nanao forearc basin from TAICRUST MCS/OBS Line 14, Terrestrial Atmospheric and Oceanic Sciences 9(1998) 345-362.

[77] E.R. Flueh, M.A. Fisher, J. Bialas, R. Jonathan, D. Klaeschen, N. Kukowski, T. Parsons, D.W. Scholl, U. ten Brink, A.M. Trehu, N. Vidal, New seismic images of the Cascadia subduction zone from cruise SO108-ORWELL, Tectonophysics 293(1998) 69-84.

[78] A.U. Stavenhagen, E.R. Flueh, C. Ranero, K.D. McIntosh, T. Shipley, G. Leandro, A. Schulze, J.J. Danobeitia, Seismic wide-angle investigations in Costa Rica: A crustal velocity model from the Pacific to the Caribbean coast, Zent. Geol. Paleont. 3-6(1998) 393-408.

[79] D. Lizzaralde, Crustal structure of rifted and convergent margins: The U.S. East Coast and Aleutian margins, Ph.D. thesis, Woods Hole, Mass., 1997.

\section{Figure and table captions}

Figure 1: General map of the eastern part of the Nazca plate and of the southern Colombia and Ecuador margin. Seafloor topography is derived from satellite altimetry and ship depth soundings [71] completed by available swath mapping $[4,20]$. It is contoured at $500 \mathrm{~m}$ intervals between -5000 and $-500 \mathrm{~m}$, and $25 \mathrm{~m}$ intervals between -250 and the coastline. Heavy solid black lines show locations of the three wide-angle seismic profiles used in this work. White circles: locations of OBSs along each profile. Bold circles: same as white circles for sections shown in Fig. 2 to 5. White triangles: land station locations. White line is wide-angle seismic refraction line published in [33]. Stars: epicentres of the six great subduction earthquakes that occurred along the margin since 1901, including four in the northern part $\left(3.5^{\circ} \mathrm{N}-0.5^{\circ} \mathrm{S}\right)$. The most important $(1906, \mathrm{Mw}=8.8)[68]$ has partially been reactivated three times from south to north: $1942(\mathrm{Mw}=7.9), 1958(\mathrm{Mw}=7.8)$ and $1979(\mathrm{Mw}=8.2)$ $[67,69]$. In contrast, no major earthquakes have been reported in the southern part of the study area $\left(0.5^{\circ} \mathrm{S}-3^{\circ} \mathrm{S}\right)$, except two poorly documented events in 1901 and 1953. Dashed contours: rupture zone of the 1958 and 1979 earthquakes [27]. Bold arrow: relative convergence between Nazca Plate and North Andean Block from GPS 
data. DGM: Dolores-Guayaquil Megashear. Location of Cayo and Piñon formation outcrops and their equivalent in Colombia (Diabasico formation) are in red and orange (after the geologic maps of Ecuador and Colombia).

Figure 2: Examples of wide-angle seismic data, picked and calculated travel times and corresponding ray paths for the best fitting velocity model (Fig. 5a) along profile SAL-6 (North Ecuador) for OBH 116 (left) and OBS 121 (right). (top) Seismic record section for vertical geophone after data preprocessing (deconvolution, $5-15 \mathrm{~Hz}$ Butterworth filter, equalization); (middle) picked (solid circles with error bars) and predicted (open circles) travel times for first arrival phases (Pg and Pn) and refraction from the Moho (PmP); (bottom) Corresponding ray tracing for all identified seismic phases. The black arrows point at the trench location.

Figure 3: same as Fig. 2 for profile SIS-4 (Carnegie Ridge), OBS 04 (left) and OBS 10 (right) for the best fitting velocity model (Fig. 5b).

Figure 4: same as Fig. 2 for profile SAL-2 (Gulf of Guayaquil), OBH 45 (left) and OBS 57 (right) except hydrophone component is shown for OBH 45. Best fitting velocity model (Fig. 5c).

Figure 5: Results of tomographic inversion of $\mathrm{Pg}, \mathrm{Pn}$ and $\mathrm{PmP}$ arrivals. Iteration steps and RMS travel time misfits are displayed in table 2. Models are displayed from north to south : (a) profile 6, Northern Ecuador; (b) profile 4, Carnegie Ridge; (c) profile 2, Gulf of Guayaquil. White circles: OBS and land stations locations; solid black lines: location of the Moho interface inverted from PmP arrivals; white dashed line: base of sedimentary cover derived from coincident MCS data (Fig. 8); black dots: top of the oceanic crust from coincident MCS data converted to depth; whites dots: top of the subduction channel (decollement) derived from coincident MCS data converted to depth; red dots: interpreted splay fault derived from coincident MCS data converted into depth; the vertical grey line correlate the trench location from one profile to another.

Figure 6: Results of the Monte-Carlo analysis and ray tracing representation for (a) profile SAL-6; (b) profile SIS-4; (c) profile SAL-2.

(1) Final velocity model derived from averaging all Monte-Carlo ensembles, the average models are computed by taking the mean values of the 100 final models at each point of the grid; the two dashed lines indicates the variation in Moho location for the 100 Monte-Carlo inversions.

(2) Corresponding velocity and Moho depth uncertainties (contours interval is set at $0.05 \mathrm{~km} / \mathrm{s}$ ). The velocity uncertainties correspond to the average of the absolute difference between the average velocity derived from the 100 final models at each node of the model and the velocity obtained for each of the 100 final models at the same node.

(3) Derivative weight sum (DWS) provides a quantitative representation of the ray coverage (in white) calculated in the best final velocity models (Fig. 5).

Uncertainties are much larger in the lower part of the models (imaged by PmP and Pn phases only), than in the upper crust ( $\sim 0.15$ to $0.20 \mathrm{~km} / \mathrm{s}$ ) along all profiles. In profile SIS-4, the number of Pn and PmP picked was too small to allow a regular sampling of the crust-mantle boundary (as confirmed by the DWS) so the lower crust is poorly resolved. Uncertainty of Moho depths is usually lower than $5 \mathrm{~km}$, the maximum is reached beneath the margin where the Moho is deeper and velocity uncertainties higher than $0.15 \mathrm{~km} / \mathrm{s}$. In the shallower part of the floating reflector (seaward each profile) the depth uncertainty is generally smaller than $3 \mathrm{~km}$.

Figure 7: Results of the checkerboard tests for (a) profile SAL-6; (b) profile SIS-4; (c) profile SAL-2. The synthetic models consist of the addition of two sinusoidal velocity anomalies $(8 * 5 \mathrm{~km}$ in the upper part of the model; and $25^{*} 12 \mathrm{~km}$ in the lower part) featuring periodic positive and negative amplitudes (up to $\pm 5 \%$ ) to the best fitting velocity models (Fig. 5). The same source receiver geometry is used to compute synthetic travel times but random noise is added. Subsequently, these synthetic data sets are inverted, starting from the corresponding unperturbed models. (1) True model perturbation showing the amplitude and geometry of velocity anomalies; (2) recovery of anomalies obtained after four iterations. The Moho geometry is successfully recovered with an uncertainty of less than $1 \mathrm{~km}$. Thus, we can suggest that the velocity-depth ambiguity raised by the tomography is insignificant in our study and that the data sets have enough spatial resolution to resolve velocity anomalies with the size and amplitude of the ones considered here.

Figure 8: Multichannel seismic reflection line SIS-44 across the margin wedge [27]. This MCS line is coincident with profile SAL-6 (see location in fig. 1). (top) Line drawing of line SIS-44 showing the splay fault, the decollement and the top of oceanic crust as interpreted from [27] and used in this study (Fig. 5). (bottom) Close-up showing the splay fault that is connected to a summit graben associated with a gentle rise of seafloor. The splay fault appears to connect to the decollement at depth. 
Figure 9: Velocity logs showing vertical velocity variation below the top of basement (assumed to start at 4 $\mathrm{km} / \mathrm{s}$ ) versus depth across the margin $25 \mathrm{~km}$ east of the trench (left) and $60 \mathrm{~km}$ east of the trench (right) for profile SAL-6 (red), profile SIS-4 (green) and profile SAL-2 (blue). The thickness of the curves represents the uncertainty of the velocity inferred from the previous Monte-Carlo analysis. (dashed lines): location of the interplate contact zone.

Figure 10: Seismicity of the Ecuador-Colombia margin. (a) Hypocenters from 1973 to 2006 are from the USGS National Earthquakes Information Center.

On line data available at http://neic.usgs.gov/neis/epic/epic.html.

(b) Earthquake fault plane solutions from the Global Centroid Moment Tensor (CMTS) database from 1976 to 2006 [72]. On line data available at http://www.globalcmt.org/

Table 1: Profiles characteristics and model parameterization, showing the number of instruments, the number of picked arrivals, the model dimensions and the grid spacing chosen for the tomographic inversion. OBS/OBH spacing ranges from $5 \mathrm{~km}$ (SAL-6 and SAL-2) to 10-12 km (SIS-4).

Table 2: Inversion parameters used to obtain the final tomographic models displayed in Fig. 5. Different combinations of correlation length values were tested, and we have noted that varying these parameters by $50 \%$ does not significantly affect the overall smoothness in the resulting final models. In order to force convergence, we choose to lower the smoothing and damping constraints values during iterations, dividing the inversion into two to three steps depending on the model considered. Several combinations of values were tested, but the best results were obtained with the procedure depicted in this table. The depth kernel weighting is unvarying $(\mathrm{w}=1)$ allowing an equal weight to both refracted and reflected phases during inversion.

Table 3: Quantification of the fit between observed and computed travel times for the best fitting (Fig. 5) and the mean models (Fig. 6).

Table 4: Synthetic view on the results obtained along the three profiles.

Table 5: Worldwide margin wedge velocities from wide-angle surveys (the highest velocity $40 \mathrm{~km}$ from the trench is used to sort the data). This table is after the compilation of [45] with some additional recent studies. The low $(<3.0 \mathrm{~km} / \mathrm{s})$ surficial velocities associated with a slope apron are not included, for tomographic inversion this lower limit was arbitrarily taken at $3.5 \mathrm{~km} / \mathrm{s}$ (velocities in parenthesis) 


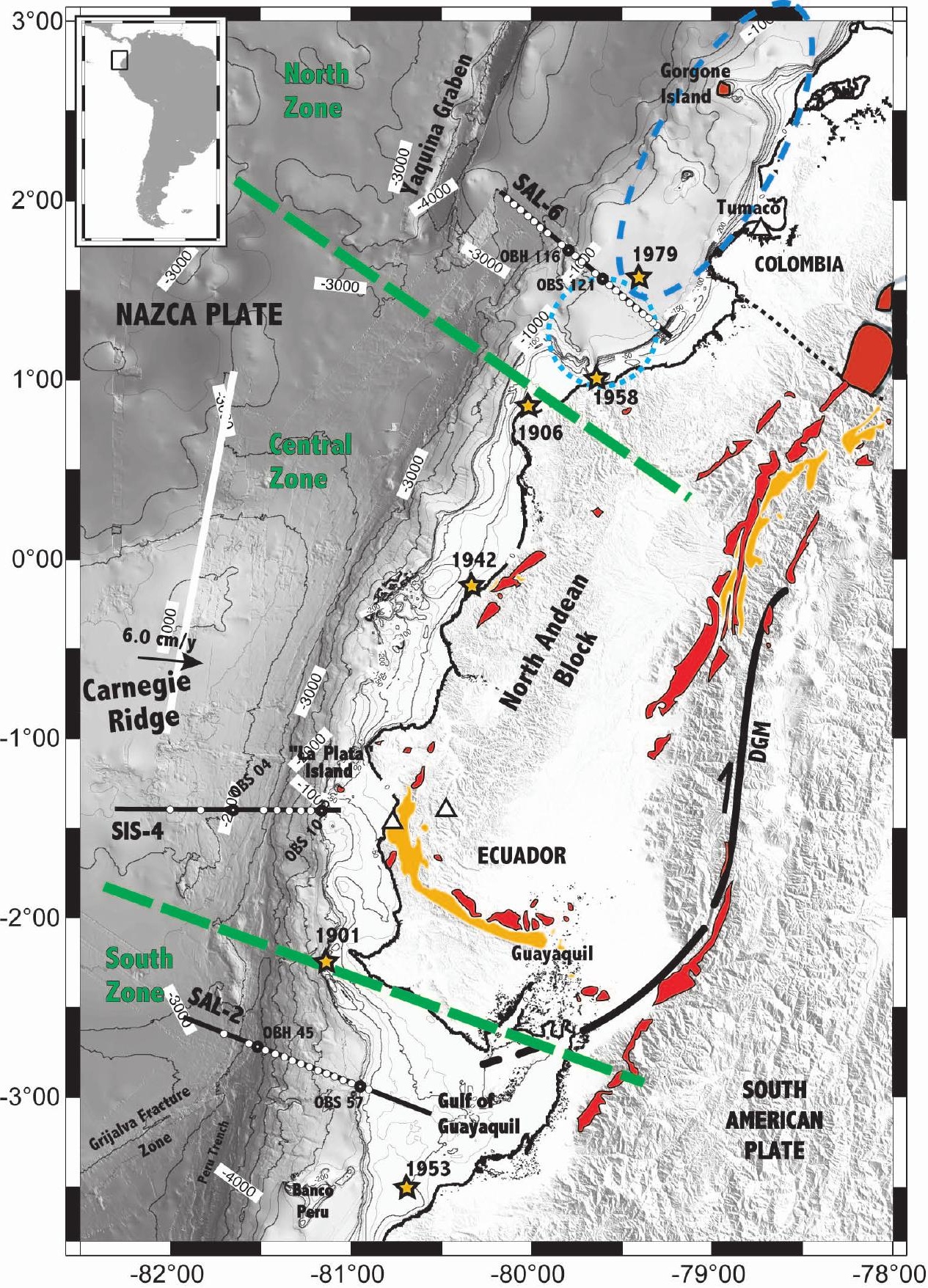



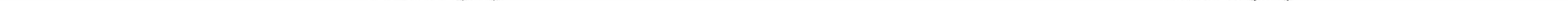


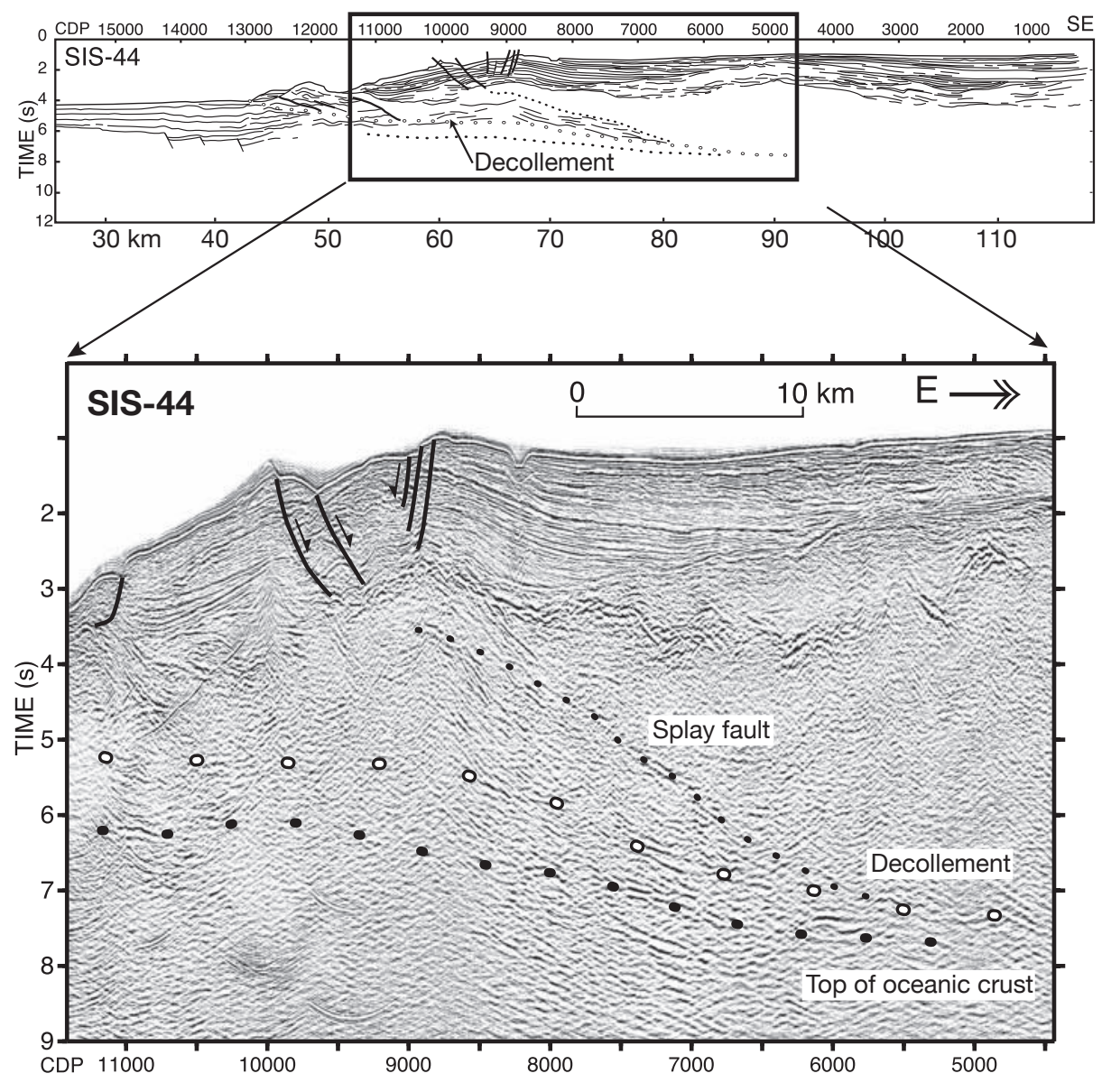



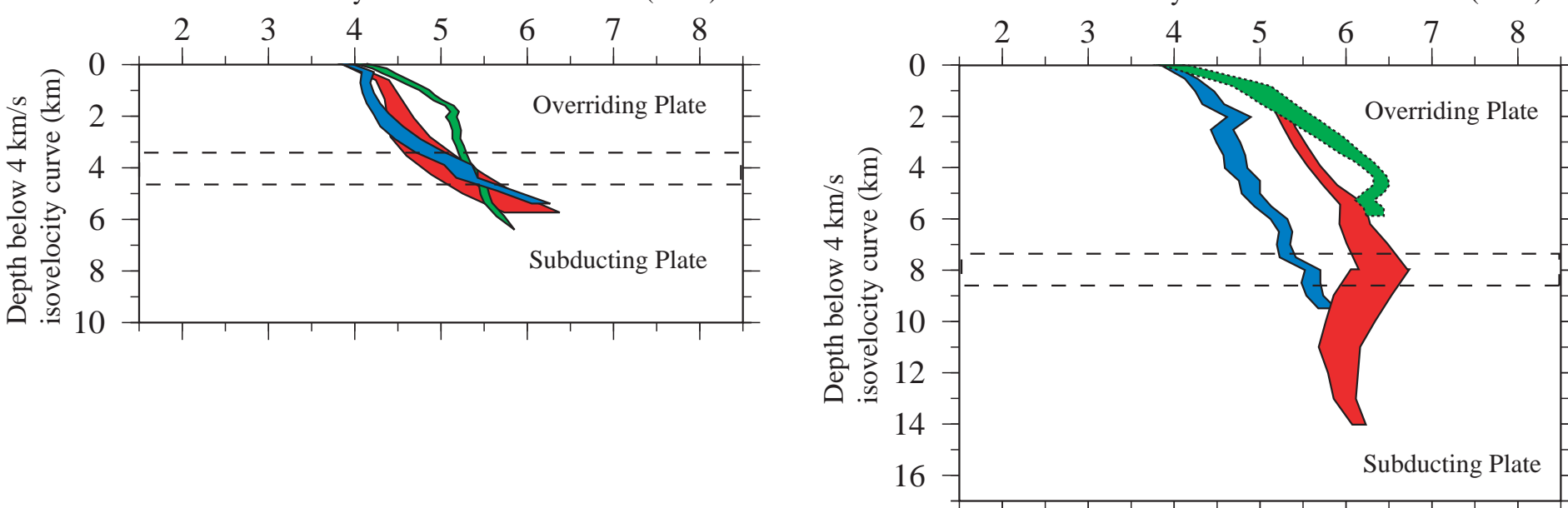

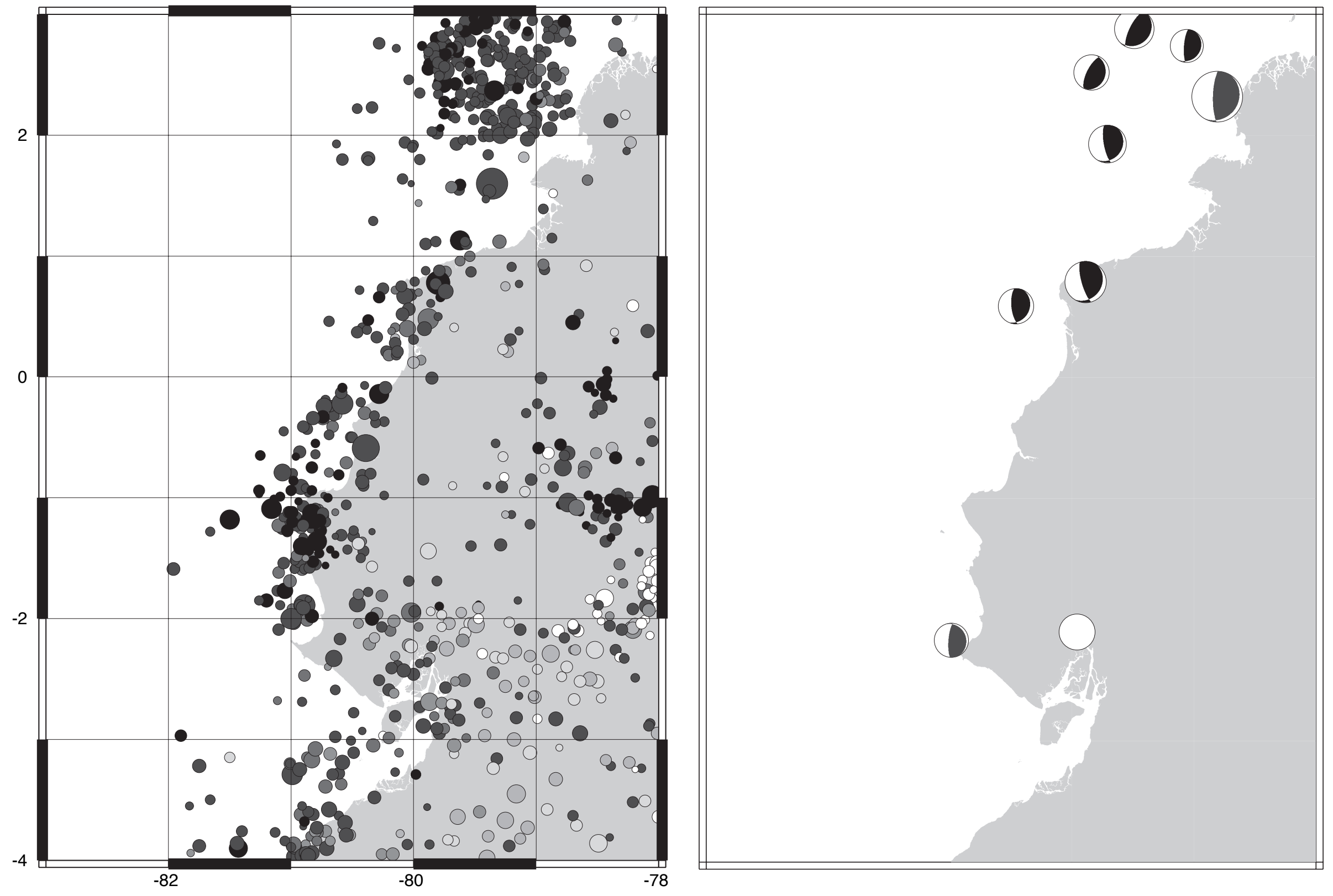


\begin{tabular}{|c|c|c|c|c|c|c|c|c|c|c|}
\hline \multirow{3}{*}{ Profile } & \multirow{3}{*}{$\begin{array}{l}\text { Number of } \\
\text { instruments }\end{array}$} & \multicolumn{2}{|c|}{$\begin{array}{c}\text { number of } \\
\text { picks }\end{array}$} & \multicolumn{2}{|c|}{ Model Dimensions } & \multicolumn{5}{|c|}{ Grid Spacing } \\
\hline & & \multirow[b]{2}{*}{ Pg-Pn } & \multirow[b]{2}{*}{ PmP } & \multirow[b]{2}{*}{$\mathrm{X}(\mathrm{km})$} & \multirow[b]{2}{*}{$\mathrm{Z}(\mathrm{km})$} & \multirow{2}{*}{$\begin{array}{l}\text { Number of } \\
\text { nodes }\end{array}$} & \multirow{2}{*}{$\begin{array}{l}\text { Horizontal } \\
\qquad(\mathrm{km})\end{array}$} & \multicolumn{2}{|c|}{ Vertical $(\mathrm{km})$} & \multirow{2}{*}{$\begin{array}{r}\text { Reflector node } \\
\text { spacing }(\mathrm{km})\end{array}$} \\
\hline & & & & & & & & $\begin{array}{c}\text { Top of the } \\
\text { model }\end{array}$ & $\begin{array}{l}\text { Bottom of the } \\
\text { model }\end{array}$ & \\
\hline SAL-6 & 22 & 4611 & 701 & 137 & \multirow{3}{*}{30} & 10564 & \multirow{3}{*}{0.5} & \multirow{3}{*}{0.1} & \multirow{3}{*}{2} & \multirow{3}{*}{1} \\
\hline SIS-4 & 11 & 1043 & 269 & 210 & & 26523 & & & & \\
\hline SAL-2 & 16 & 3707 & 374 & 163 & & 17331 & & & & \\
\hline
\end{tabular}




\begin{tabular}{|c|c|c|c|c|c|c|c|c|c|c|c|c|c|c|}
\hline \multirow{3}{*}{ Profile } & \multirow{3}{*}{$\begin{array}{c}\text { Total } \\
\text { number of } \\
\text { iterations }\end{array}$} & \multirow{3}{*}{$\begin{array}{l}\text { Iteration } \\
\text { step }\end{array}$} & \multicolumn{2}{|c|}{$\begin{array}{l}\text { Smoothing } \\
\text { parameters }\end{array}$} & \multicolumn{2}{|c|}{$\begin{array}{c}\text { Damping } \\
\text { parameters }\end{array}$} & \multicolumn{4}{|c|}{ Correlation Length $(\mathrm{km})$} & \multicolumn{2}{|c|}{ RMS (s) } & \multicolumn{2}{|c|}{$x^{2}$} \\
\hline & & & \multirow[b]{2}{*}{$\begin{array}{c}\text { In depth } \\
(\%)\end{array}$} & \multirow[b]{2}{*}{$\begin{array}{c}\text { In } \\
\text { velocity } \\
(\%)\end{array}$} & \multirow[b]{2}{*}{$\begin{array}{c}\text { In depth } \\
(\%)\end{array}$} & \multirow[b]{2}{*}{$\begin{array}{l}\text { In } \\
\text { velocity } \\
(\%)\end{array}$} & \multicolumn{2}{|c|}{ Horizontal } & \multicolumn{2}{|c|}{ Vertical } & \multirow[b]{2}{*}{$\begin{array}{c}\text { Starting } \\
\text { model }\end{array}$} & \multirow[b]{2}{*}{$\begin{array}{l}\text { Final } \\
\text { model }\end{array}$} & \multirow[b]{2}{*}{$\begin{array}{c}\text { Starting } \\
\text { model }\end{array}$} & \multirow[b]{2}{*}{$\begin{array}{l}\text { Final } \\
\text { model }\end{array}$} \\
\hline & & & & & & & $\begin{array}{l}\text { Top of } \\
\text { the } \\
\text { model }\end{array}$ & $\begin{array}{l}\text { Bottom } \\
\text { of the } \\
\text { model }\end{array}$ & $\begin{array}{l}\text { Top of } \\
\text { the } \\
\text { model }\end{array}$ & $\begin{array}{l}\text { Bottom } \\
\text { of the } \\
\text { model }\end{array}$ & & & & \\
\hline \multirow{2}{*}{ SAL-6 } & \multirow{2}{*}{12} & 1 to 8 & 15 & 50 & 10 & 50 & \multirow{2}{*}{3} & \multirow{2}{*}{9} & \multirow{2}{*}{0.5} & \multirow{2}{*}{9} & \multirow{2}{*}{0.852} & \multirow{2}{*}{0.085} & \multirow{2}{*}{212.29} & \multirow{2}{*}{2.25} \\
\hline & & 9 to 12 & 15 & 30 & 10 & 10 & & & & & & & & \\
\hline \multirow{2}{*}{ SIS-4 } & \multirow{2}{*}{13} & 1 to 8 & 15 & 50 & 10 & 50 & \multirow{2}{*}{3} & \multirow{2}{*}{9} & \multirow{2}{*}{0.5} & \multirow{2}{*}{9} & \multirow{2}{*}{0.507} & \multirow{2}{*}{0.087} & \multirow{2}{*}{71.56} & 14 \\
\hline & & 9 to 13 & 15 & 30 & 10 & 10 & & & & & & & & 2.44 \\
\hline & & 1 to 8 & 15 & 50 & 10 & 50 & & & & & & & & \\
\hline SAL-2 & 16 & 9 to 12 & 15 & 30 & 10 & 10 & 3 & 9 & 0.5 & 9 & 1.847 & 0.092 & 1618.55 & 3.37 \\
\hline & & 13 to 16 & 5 & 15 & 5 & 5 & & & & & & & & \\
\hline
\end{tabular}





\begin{tabular}{|c|c|c|c|c|}
\cline { 2 - 5 } \multicolumn{1}{c|}{} & \multicolumn{2}{c|}{ RMS } & \multicolumn{2}{c|}{$\chi^{2}$} \\
\cline { 2 - 5 } Best Inversion & $\begin{array}{c}\text { starting } \\
\text { average model }\end{array}$ & $\begin{array}{c}\text { final average } \\
\text { model }\end{array}$ & $\begin{array}{c}\text { starting } \\
\text { average model }\end{array}$ & $\begin{array}{c}\text { final average } \\
\text { model }\end{array}$ \\
\hline profile SAL-6 & 0.852 & 0.085 & 212.29 & 2.25 \\
\hline profile SIS-4 & 0.507 & 0.087 & 71.56 & 2.44 \\
\hline profile SAL-2 & 1.847 & 0.092 & 1618.55 & 3.37 \\
\hline
\end{tabular}

\begin{tabular}{|c|c|c|c|c|}
\cline { 2 - 5 } \multicolumn{1}{c|}{} & \multicolumn{2}{c|}{ RMS } & \multicolumn{2}{c|}{$\chi^{2}$} \\
\hline Average Models & $\begin{array}{c}\text { starting } \\
\text { average model }\end{array}$ & $\begin{array}{c}\text { final average } \\
\text { model }\end{array}$ & $\begin{array}{c}\text { starting } \\
\text { average model }\end{array}$ & $\begin{array}{c}\text { final average } \\
\text { model }\end{array}$ \\
\hline profile SAL-6 & 0.776 & 0.199 & 168.556 & 12.563 \\
\hline profile SIS-4 & 0.466 & 0.092 & 59.590 & 2.448 \\
\hline profile SAL-2 & 1.919 & 0.132 & 1744.570 & 6.605 \\
\hline
\end{tabular}




\begin{tabular}{|c|c|c|c|c|c|c|c|c|c|}
\hline \multirow{2}{*}{ Zone } & \multirow{2}{*}{$\begin{array}{l}\text { Slab Dip } \\
\left(^{\circ}\right)\end{array}$} & \multirow{2}{*}{$\begin{array}{c}\text { Oceanic } \\
\text { Crustal } \\
\text { Thickness } \\
(\mathrm{km})\end{array}$} & \multicolumn{4}{|c|}{ Sediments Thickness $(\mathrm{km})$} & \multicolumn{2}{|c|}{$\begin{array}{l}\text { Vertical velocity gradient in the margin } \\
\text { basement }(\mathrm{km} / \mathrm{s} / \mathrm{km})\end{array}$} & \multirow{2}{*}{$\begin{array}{l}\text { Distance } \\
\text { from trench } \\
\text { for HVB } \\
\quad(\mathrm{km})\end{array}$} \\
\hline & & & Oceanic Plate & Trench & Slope & Margin & $\begin{array}{l}\text { at } 25 \mathrm{~km} \text { from } \\
\text { the trench }\end{array}$ & at $60 \mathrm{~km}$ from the trench & \\
\hline $\begin{array}{l}\text { North }\left(3^{\circ} \mathrm{N}\right. \\
\left.1^{\circ} \mathrm{N}\right)\end{array}$ & $4-8$ & 6 & $1-2$ & $2-3$ & 2 & 3 & 0.30 & $\begin{array}{c}0.21 \text { (before LVZ) } \\
0.08 \text { (with LVZ) }\end{array}$ & 35 \\
\hline $\begin{array}{c}\text { Central } \\
\left(1^{\circ} \mathrm{N}-2.5^{\circ} \mathrm{S}\right)\end{array}$ & $4-10$ & 15 & 0.5 & 0.5 & 1 & $1 ?$ & 0.18 & $\mathrm{X}$ & 25 \\
\hline $\begin{array}{c}\text { South } \\
\left(2.5^{\circ} \mathrm{S}-3.5^{\circ} \mathrm{S}\right)\end{array}$ & $4-6$ & 7 & 0.5 & $1-2$ & 1 & 5 & 0.37 & 0.16 & $\mathrm{X}$ \\
\hline
\end{tabular}




\begin{tabular}{|c|c|c|c|}
\hline \multirow[t]{2}{*}{ Region } & \multicolumn{2}{|l|}{ Velocity range, $\mathrm{km} / \mathrm{s}$} & \multirow[t]{2}{*}{ Reference } \\
\hline & $20 \mathrm{~km}$ from trench & $40 \mathrm{~km}$ from trench & \\
\hline Taiwan, Hengchun Peninsula & $3.3-3.6$ & $3.3-4.0$ & {$[72]$} \\
\hline Alaska, Kodiak & $3.0-3.3$ & $3.6-4.2$ & {$[73]$} \\
\hline Chile, Valparaiso & $3.0-4.0$ & $3.0-4.2$ & {$[74]$} \\
\hline Taiwan, Ryukyu trench & $3.5-3.7$ & $3.5-4.3$ & {$[75]$} \\
\hline Cascadia, Washington & $3.5-4.2$ & $3.2-4.4$ & {$[76]$} \\
\hline Western Nankai Trough & $3.5-4.4$ & $3.5-4.5$ & {$[59]$} \\
\hline Ecuador, Gulf of Guayaquil & $(3.5)-4.5$ & $(3.5)-5.0$ & $\begin{array}{l}S A L-2 \\
\text { this study }\end{array}$ \\
\hline Costa Rica, NW of Osa Peninsula & 4.0 & $4.0-5.0$ & {$[77]$} \\
\hline Eastern Nankai Trough & $(3.5)-4.0$ & $(3.5)-5.2$ & {$[53]$} \\
\hline Eastern Nankai Trough & $3.0-4.2$ & $2.8-5.3$ & {$[54]$} \\
\hline North Ecuador, South Colombia & $(3.5)-5.0$ & $(3.5)-5.4$ & $\begin{array}{l}\text { SAL-6, } \\
\text { this study }\end{array}$ \\
\hline Cascadia, Oregon & $3.0-4.0$ & $3.0-5.5$ & [49] \\
\hline Cascadia, Oregon & $3.5-4.0$ & $3.5-4.5$ & {$[47]$} \\
\hline Alaska, Shumagin & $3.2-4.7$ & $3.1-6.0$ & {$[78]$} \\
\hline Central Peru, Lima & $4.3-5.2$ & $5.0-5.6$ & {$[56]$} \\
\hline Chile, Antofagasta & $(3.5)-5.2$ & $(3.5)-5.7$ & {$[45,78]$} \\
\hline Northern Peru, Trujillo & $4.4-5.3$ & $4.6-5.7$ & {$[56]$} \\
\hline Costa Rica, Nicoya Peninsula & 4.4-4.9 & $4.8-6.2$ & {$[44]$} \\
\hline Central Ecuador, La Plata Island & $(3.5)-5.7$ & $(3.5)-6.2$ & $\begin{array}{l}\text { SIS-4, } \\
\text { this study }\end{array}$ \\
\hline
\end{tabular}

